\title{
The Authority of the Court Against the Decision of the Indonesian National Arbitration Board (BANI) in the Settlement of Business Disputes in the Perspective of Legal Certainty
}

\author{
Herwastoeti ${ }^{1}$ \\ \{herwastoeti@gmail.com\} \\ Faculty of Law, University of Muhammadiyah Malang, Indonesia
}

\begin{abstract}
Article 70 of Law No. 30 of 1999 concerning Arbitration and Alternative Dispute Resolution (AAPS Law), opens the possibility for parties to submit requests to cancel an arbitration award. But the explanation of article 70 of the AAPS Law explains that the request for cancellation must be proven by a court ruling, this makes the existence of legal uncertainty so that it creates as if there is a new norm. This study wants to find out the legal position of the decision of the Indonesian National Arbitration Board (BANI) in resolving business disputes and examine the court's authority over the BANI's decision related to canceling the decision in the perspective of legal certainty. The method used in this study is normative (doctrinal) legal research sourced from secondary data. The results showed the Constitutional Court Decision No. No. 15 / PUU-XII / 2014 concerning the explanation of Article 70 of the AAPS Law has juridical implications for the cancellation of the arbitration award stipulated in Article 70 of the AAPS Law. Then the judge in examining an application for an annulment of arbitration does not require another court decision so that he can directly examine and assess the evidence presented in the court in the request to cancel the decision of BANI, thus providing more legal certainty.
\end{abstract}

Keywords: Business Dispute, Arbitration.

\section{Introduction}

Basically the parties involved in the business world want everything to go according to what has been planned. However, in practice sometimes what has been agreed between the two parties cannot be carried out because one of the parties has a different interpretation from what has been agreed as stated in the contract so that it can cause disputes [1]. Disputes that occur will lead to disputes between the parties in the implementation of the agreement because in addition to differences in perception of the agreement, but also because one of the parties default or commit an act against the law (onrechtmatigedaad). 
As Cut Memi's opinion that in general there are several things that cause business disputes, first, because of different interpretations of the contents of the articles in the agreement that determine the rights and obligations of both parties; secondly, differences of opinion regarding how to implement contractual rights and obligations, so that this can also lead to a default [2]. If that happens, then disputes between the parties can be reached in two ways, namely through the court (litigation) or through the mechanism of dispute resolution outside the court (non litigation).

In the business world, dispute resolution in court (litigation) and dispute resolution outside the court (non litigation) is the last choice because in business activities disputes between business people are unprofitable, so this must be avoided. However, if a dispute occurs, settlement outside the court (non-litigation) is an alternative. The choice of resolving disputes outside the court (non litigation) becomes an alternative because settlement in court (litigation) goes through a long process because it takes time and effort. This is possible because a civil lawsuit through the court one of the parties can make an appeal, appeal and review (PK). It is different if the settlement is done outside the court through Arbitration because the settlement is final and binding.

Settlement of disputes outside the court is accommodated by the enactment of Law Number 30 of 1999 concerning Arbitration and Alternative Dispute Resolution, hereinafter referred to as the AAPS Law and also the formation of the Indonesian National Arbitration Board (BANI). The choice of dispute resolution through Arbitration is based on the wishes of the parties both agreed before the implementation of the agreement and the agreement after the dispute [3].

Definition of arbitration according to Law No. 30 of 1999 concerning Arbitration and Alternative Dispute Resolution, (AAPS Law):"Arbitration is a way to settle a civil dispute outside the general court based on an arbitration agreement made in writing by the parties to the dispute."

Bryan A. Garner in the Black's Law Dictionary defines arbitration "A method of dispute resolution involving one or more neutral third parties who are using. Agreed to the disputing parties and whose decision is binding [4].

In Indonesia, interest in resolving disputes through arbitration began to increase since the enactment of Law Number 30 of 1999 Concerning Arbitration and Alternative Dispute Resolution (AAPS Law). This development is in line with globalization in the business sector which also requires quick dispute resolution, so that business people choose dispute resolution through Arbitration, because besides having advantages because it is fast, it also adheres to the win-win solution principle. Another advantage of the settlement through arbitration is confidential, because the trial process is closed and only the parties to the dispute may be present.

This was also stated by Joni Emirzon, that the method of settlement through arbitration is one of the alternative dispute resolution that provides many advantages, such as cheap and faster, maintained confidentiality, decisions that are final and binding. This is because the settlement through litigation (court) requires a long time so it is not profitable for business people if the dispute resolution must be resolved through litigation or in court [5].

Other definitions of arbitration as stated in the rules of procedure BANI (Indonesian National Arbitration Board):"Arbitration is to provide a fair and fast resolution in civil disputes arising concerning trade, industry, finance, both national and international in nature." 
Riskin and Westbrook in his book, Dispute Resolution and Lawyer, American Casebook Series: "Arbitration is a form of adjudication in which neutral decision makers are not judges or officials of administrative institutions. There is no single, comprehensive definition of arbitration that accurately explains all arbitration systems [6].

However, the AAPS Law states that not all disputes can be resolved by arbitration. According to the AAPS Law Article 5 paragraph (1) which can be resolved through an arbitration institution is only a dispute in the field of trade and concerning rights which according to the laws and regulations are fully controlled by the party in dispute. Furthermore, in paragraph (2) it is determined that a dispute that cannot be resolved through an arbitration institution is a dispute which according to the laws and regulations cannot be held peacefully.

Therefore, the arbitration clause is an agreement or agreement as outlined by the parties in the agreement. The principles contained in the principle of pacta sunt servanda and Article 1338 of the Civil Code fully apply to the arbitration agreement as stipulated in the provisions of Article 3 of the AAPS Act which says that the District Court is not authorized to adjudicate disputes of parties who have been bound in an arbitration agreement.

Although Article 60 of the AAPS Act states that the arbitration award is final and has permanent legal force and is binding on the parties, nevertheless, Article 70 of the AAPS Law opens the possibility for the parties to submit a request for cancellation. So that in practice Arbitration decisions through BANI many cancellations are submitted to the court by one of the parties to the dispute. Based on the background of the problems that have been described, the authors would like to examine in depth in this study, namely: 1 . What is the legal position of the decision of the Indonesian National Arbitration Board (BANI) in business disputes in Indonesia 2. How is the Court's authority over the BANI's decision related to the cancellation of the decision in perspective legal certainty.

\section{Method}

The method used in this research is normative legal research. Normative legal research is often referred to as doctrinal legal research. Terry Hutchinson, as quoted by Jhonny Ibrahim, in his description of normative legal research explains: "Doctrinal research is library based, focusing on reading and analysis of primary and secondary materials. The primary materials are the actual sources of law legislations and case law. The secondary materials include the commentary on the law found in the textbooks and legal journals. Often, reference sources such as legal encyclopedia, case digest and case citators are needed to index and access the primary sources [7]. Normative legal research is not familiar with field research because the material studied is legal material, so it can be said to be library based, focusing on reading and analysis of primary and secondary materials. In this study using research source collection techniques in the form of library research techniques or secondary data. Peter Mahmud Marzuki called it the statute approach, [8]. In this study called the normative juridical approach (doctrinal), an approach by examining all the laws and regulations related to legal issues. Analysis of research materials is an activity to solve and describe the 
problems studied based on the materials that have been collected. The analysis technique in writing this law with the analysis of legal substance (approach of legal content analysis). If you use this type of research, then there are three gradations of normative analytical approaches that can be used, namely: 1. Legal exploration. 2. Legal review 3. Legal analysis [9]. The approach used in this research is the application of analytical normative legal substance (approach of legal content analysis). Based on this, the steps that can be taken are by legal review and legal analysis.

\section{Results and Discussion}

\subsection{Legal Status of the Decision of the Indonesian National Arbitration Board (BANI) in Resolving Business Disputes}

BANI has an Arbitrator consisting of experts in the field of business law. Decision makers in arbitration are called Arbitrators who have expertise in their fields. At present BANI has more than 100 arbitrators with backgrounds from various professions and experts in the business field, meaning different from the settlement in court because the judge does not always understand the business dispute cases disputed by parties who work in court.

BANI examines a case based on the provisions of Article 2 of the AAP Law which is based on a specific legal relationship that has entered into an arbitration agreement that expressly states that all disputes or dissent arising or that may arise from the legal relationship will be resolved by arbitration. The arbitration clause is the basis for a dispute decided by the Arbitration Institute, (BANI). The existence of an arbitration agreement clause nullifies the right of the parties to the agreement to submit the dispute to the District Court as referred to in article 3 of the AAPS Law.

Concerning the arbitration agreement or clause is the basis for dispute resolution through arbitration, so the principle that develops in the field of contract law, namely pacta sunt servanda, has an important meaning in arbitration related to the nature of the agreement or arbitration clause [10]. The principle of pacta sunt servanda contained in Article 1338 of the Civil Code explains "All agreements made in accordance with the law apply as the law for those who make it."

Thus the arbitration clause is absolutely binding for the parties who have agreed either before the dispute or after the dispute. The arbitration clause cannot be withdrawn secretly, or carried out unilaterally canceled / not recognized by one of the parties. However, it is possible to be withdrawn by agreement of the parties to the dispute, meaning that the arbitration clause does not apply if the parties expressly cancel.

The District Court must refuse and not interfere in resolving disputes that have been determined through arbitration, except in certain cases stipulated in this law as stipulated in article 11 of the AAPS Law" the parties to submit a dispute resolution or dissent included in the agreement to the District Court. " Court interference is only possible in certain matters such as in the case of execution or cancellation of the arbitral award must also be expressly regulated in state law [11].

The legal status of the BANI decision is absolute and the Court may not examine the arbitral award as affirmed in Article 62 paragraph (4) of the AAPS Law "The Head of the District Court does not examine the reasons or considerations of the Arbitration award." Accordingly, the 
Chairperson of the District Court does not have the authority to review an arbitration award materially. However, judges in Indonesia are not always guided by the provisions of the AAPS Law, as research conducted by Cut Memi on BANI Decision Number 399 / V / ARB-BANI / 2011 dated November 1, 2011, was later canceled by the Central Jakarta District Court with Decision Number 528 / Pdt .G / ARB / 2011, on March 28, 2012.

The judge accepted the plaintiff's cancellation request, saying the plaintiff had never agreed to the provisions of the arbitration clause contained in both the Lump Sum Contract Conditions and the Lump Sum Contract Agreement. [12]. Then the judge decided to cancel the BANI ruling based on legal considerations that the arbitration award handed down based on an arbitration clause that was not agreed upon and not signed by one of the parties in this case BANI Decision Number 399 / V / ARB-BANI / 2011 dated November 1, 2011, was contradictory with the provisions of Article 4 paragraph (2) of the AAPS Law, which requires an arbitration agreement or clause to be contained in a document signed by the parties. Therefore it is legal to cancel an a quo arbitration award, even though the cancellation is not based on the reasons stated in Article 70 of the AAPS Law, but because according to the Assembly, Article 70 of the AAPS Law is only applied when all parties agree arbitration clause. According to judges Article 70 of the AAPS Act, it is only applicable when all parties agree with the arbitration clause.

Even though the parties to the dispute have been bound by the agreement in both the Lump Sum Contract Conditions and the Lump Sum Contract Agreement which contains the arbitration clause. However, by one of the parties denied and used as a reason to cancel the decision of BANI. Though it is clear that the contract made contains an arbitration clause so that the District Court should reject the request for a cancellation of the BANI decision because it is clear that the arbitration clause has entered the contract which means that the parties have agreed that if a dispute occurs then the settlement is settled through the arbitration institution.

So the reason for not having agreed an arbitration clause is an unacceptable reason. The arbitration clause included in the principal agreement of the parties is referred to as the pactum de compromittendo clause. Form pactum de compromittendo clause of the parties binding the agreement will settle disputes through an arbitration forum before a real dispute occurs, this is as regulated in article 7 of the AAPS Law.

There are two ways to make a pactum de compromittendo clause:

a. By including the arbitration clause concerned in the main agreement. This method is the most common method.

b. Pactum compromettindo clause is made separately in a separate deed.

With the provision of article 7 of the AAPS Law, the legal position of the BANI ruling should be final and binding, cancellation cannot be submitted to the District Court by one of the parties to the dispute and it should be rejected even though on the grounds that the arbitration clause included in the contract agreement has not been agreed to be resolved through the Institution Arbitration (BANI).

\subsection{The Court's Authority Against Cancellation of BANI's Decision in Settling Business Disputes in Indonesia}


As stated above, basically the arbitration award (BANI) is final and binding means that it is the final decision binding on the parties to the dispute so that no legal remedy can be made. However Article 70 of the AAPS Law opens the possibility that states that: against an arbitration award the parties may submit a request for cancellation if the decision is alleged to contain the following elements: a. Letters of documents submitted during an examination, after the verdict is handed down are acknowledged to be false or declared to be false; b. After the verdict is taken, found decisive documents, which are hidden by the opposing party; or c. The decision was taken from the results of a ruse carried out by one of the parties in the examination of the dispute.

But the explanation of article 70 of the AAPS Law also explains that the request for cancellation can only be submitted against an arbitration award that has been registered in court. The reasons for the cancellation request referred to in this article must be proven by a court decision. If the court states that the reasons are proven or not proven, then the court's decision can be used as a basis for consideration for the judge to grant or reject the petition. Therefore, if an arbitration award by one of the parties allegedly contains one of the elements specified in Article 70 of the AAPS Law, a request for cancellation can be submitted to the District Court. The request for cancellation of the arbitration award must be submitted in writing no later than 30 (thirty) days from the day of submission and registration of the arbitration award to the Registrar of the local District Court.

Explanation of Article 70 of the AAPS Act is considered to be contrary to the intent contained in Article 70 of the AAPS Act itself because it is as if the explanation of Article 70 of the AAPS Law arises a new norm, not explaining the body of Article 70 of the AAPS Law. The explanation of Article 70 of the Arbitration Law is burdensome and detrimental to the applicant, because the 30day time limit stipulated in Article 71 of the Arbitration Law will be exceeded, because it is unlikely that a criminal case can be examined and decided within 30 days. Explanation of article 70 of the AAPS Law was then submitted by the Judicial Review to the Constitutional Court. (MK). The Petitioners of the Judicial Review reasoned that the explanation in Article 70 caused confusion and legal conflict [13].

This is considered not to provide legal certainty because it raises new legal rules that conflict with the provisions contained in Article 70 of the Arbitration Law itself. With the expiry of the allotted time, it is clear that the request for cancellation of the arbitration award cannot be submitted and if it is still submitted then the opportunity will be rejected by the Panel of Judges who examined the request. In its decision, the Constitutional Court stated that the Elucidation of Article 70 of the Arbitration Law is contrary to the 1945 Constitution of the Republic of Indonesia and has no binding legal force. The Constitutional Court's consideration that the explanation of article 70 of the AAPS Law is not legal and just. As a result of the legal ruling on the issuance of the Constitutional Court, in the submission of the cancellation of the BANI ruling in accordance with the article 70 of the AAPS Law, it does not have to be proven first through a court ruling. Considering the revocation of article 70 of the AAPS Law which previously created new norms and multiple interpretations, article 70 of the AAPS Law is considered quite clear. Thus the Constitutional Court's decision can be used as a basis by the court in exercising its authority over the BANI Decision which is proposed for cancellation by one of the parties so as to provide legal certainty implications for BANI's decision. 


\section{Conclusions}

The Legal Position of the Indonesian National Arbitration Board (BANI) in resolving business disputes is final and binding, as regulated in Article 60 of the AAPS Law. However, in practice, judges sometimes ignore the provisions of article 7 of the AAPS Law, so that if the parties have entered into an arbitration agreement, then the disputing parties have no reason to deny the arbitration clause in the contract that has been made and is used as a reason to submit the cancellation of BANI's decision, then the court should refuse if the submission of cancellation is not in accordance with the provisions stipulated in Article 70 of the AAPS Law.

However, in practice, the Court Judge accepted the reason for one of the parties to the dispute on the grounds that the arbitration clause included in the contract had not been agreed upon. Decision of the Constitutional Court No. No. 15 / PUU-XII / 2014 has juridical implications for the annulment of arbitration award stipulated in Article 70 of the AAPS Law. Then the judge in examining the application for cancellation of the arbitration does not require another court decision so that it can directly examine and assess the evidence presented in the court in deciding the case for the cancellation of the award.

\section{Acknowledgments}

This article is part of the research that has been done by the author.The author would like to thank the leaders of the University of Muhammadiyah Malang who have provided research grants so that the authors can join in the 3rd International Conference on Indonesian Law Studies (ICILS) at UNNES Semarang.

\section{References}

[1] Sentosa Sembiring," Hukum Dagang”, Edisi Revisi, Cetakan ketiga, CitraAdityaBhakti,Bandung, 2008, pp. 45-46

[2] Cut Memi," Implementasi Pembatalan Putusan BANI Dan Putusan BAPMIOleh Pengadilan Negeri, Journal Yudisial, Vol. 8 No. 1, pp. 103-123, April 2015.

[3] Djoko Imbawani Atmadjaja, "Hukum Dagang Indonesia Sejarah, Pengertian dan Prinsipprinsip Hukum Dagang", Cetakan ke-2, Malang, Setara Press, pp.23-25, 2012.

[4] Bryan A. Garner, "Black's Law Dictionary, Eight Edition," United States of America, Thomson and West Publishing, Co. 1990.

[5] Joni Emirzon, “Alternatif Penyelesaian Sengketa di Luar Pengadilan, "PT. Gramedia Pustaka Utama, Jakarta, pp.32-35, 2001.

[6] Kunti Kalma Syita, "Penerapan Prinsip Dasar Pembuktian Hukum Perdata Formil dalam Arbitrase Berdasarkan UU No 30 Tahun 1999, Journal Yuridika: Volume 29 No 1, pp.17-37, Januari - April 2014, [online:] Available: https://ejournal.unair.ac.id/YDK/article/view/356/190. [7] Johnny Ibrahim, "Teori dan Metodologi Penelitian Hukum Normatif," Bayumedia Publishing, Malang, pp.37-38, 2006. 
[8] Peter Mahmud, "Penelitian Hukum”, Edisi Pertama Cetakan ke-4 Jakarta: Kencana Prenada Media Group, Jakarta, pp. 15-18, 2008.

[9] Abdulkadir Muhammad," Hukum dan Penelitian Hukum", PT Citra Aditya Bakti, Bandung, pp. 32-34, 2004.

[10] Jessicha Tengar Pamolango, "Tinjauan Yuridis Terhadap Kewenangan Arbitrase Dalam Penyelesaian Sengketa”, Journal Lex Administratum, Vol. III/No.1/Jan-Mar/, pp. 145-155,

2015, [online]. Available:

https://ejournal.unsrat.ac.id/index.php/administratum/article/vieq/8339/7901

[11] Mosgan Situmorang, "Pelaksanaan Putusan Arbitrase Nasional Indonesia (Enforcement of National Arbitration Award in Indonesia)", Journal Penelitian Hukum DE JURE, ISSN 14105632, e-ISSN 2579-8561, Vol. 17 No. 4, pp.309-320, Desember 2017.

[12] Cut Memi," Implementasi Pembatalan Putusan BANI Dan Putusan BAPMI Oleh Pengadilan Negeri, Jurnal Yudisial, Vol. 8 No. 1, pp. 103-123, April 2015.

[13] Fitriana, "Upaya Pembatalan Putusan Arbitrase ( Analisis Putusan Mahkamah Konstitusi No.15/PUU-XII/2014, Skripsi, UIN Syarif Hidayatulah, Jakarta, pp. 45-52, 2015. 